\title{
Contextualising the Punishment of Death
}

Legal writers of the late eighteenth and early nineteenth centuries recognised not only the differences between the legal systems north and south of the border, but also the differences in their use of capital punishment. An awareness of Scotland's lesser recourse to the death sentence was praised in the legal commentaries cited in Chap. 2 and Scots law was held up as a bastion of Scottish identity that had been maintained after the Union. ${ }^{1}$ However, in conducting the first extensive examination of the court records, as well as sources rich with qualitative material such as newspapers, state papers and Home Office records, this study demonstrates that Scotland witnessed significant fluctuations in its execution rate and a more frequent recourse to the death sentence for particular crimes in certain decades.

This chapter will examine three key periods in Scotland's capital punishment history. It will demonstrate that, while there were discernible similarities north and south of the border in terms of an increase in the sheer number of executions as well as an intensification of debates over criminality, the drivers behind this and the responses to it in Scotland differed markedly. In turn, an investigation into the previously neglected Scottish experience offers a unique perspective of Britain's use of the death sentence at these three crucial junctures. The opening section of this chapter will demonstrate that the mid-eighteenth century was a focal period in Scotland's penal history. It was a time when the country, particularly the Highlands, was reeling from the events of the 1745 Jacobite Rebellion (the '45) and the British government was determined to penetrate the

(C) The Author(s) 2018

R.E. Bennett, Capital Punishment and the Criminal Corpse in Scotland, 1740-1834, Palgrave Historical Studies in the Criminal Corpse and its Afterlife, https://doi.org/10.1007/978-3-319-62018-3_3 
peripheral north and establish more centralised control. Legislative assaults were made upon Highland culture and dress, and both legal and popular attitudes towards the area went some way towards shaping the implementation of the death penalty in the decade following the rebellion. The second section will focus upon the 1780s. It will show that the peak number of executions in this decade can be placed within the wider crisis facing the British authorities in transporting their criminals abroad following the temporary removal of the penal option of transportation. The final section will examine the first third of the nineteenth century. It will demonstrate that this period was one of increased debate over the use of the death sentence in the face of rising numbers of capital convictions in Britain, but it will present a unique Scottish response to the problem. In addition, it will explore the increased space dedicated to crime reporting in the Scottish newspapers and how previous acknowledgements of Scotland's lesser recourse to the death sentence turned to lamentations of its increased use in this period.

\section{Executions Following the 1745 Jacobite Rebellion}

Mid-eighteenth-century Britain witnessed intense concerns over a perceived increase in crime and public debates over punishment. However, this chapter examines a distinct Scottish response to this British problem. Within the richer historiography dedicated to England's criminal history in this period, two of the key explanations presented for the spike in execution rates were the effects of demobilisation following major wars and the occurrence of moral panics over crime within printed public discourse. A recurring link has been developed between recorded levels of crime and the impact of times of war and peace. Beattie demonstrated an evident upturn in prosecutions for property offences in Surrey as major wars ended. Following the end of the War of the Austrian Succession (17401748) the period 1749 to 1756 saw 99 people capitally convicted and, of those, $50(50.5 \%)$ were executed. In contrast, in the period 1757 to 1763 , during the Seven Years War, of 44 people capitally convicted there were $10(22.7 \%)$ executions. $^{2}$ Similar patterns have been discovered in works focused upon Staffordshire and Essex respectively in the same period. ${ }^{3}$

In addition to the threats to public order posed by demobilisation, mid-eighteenth-century England also witnessed moral panics over the feared prevalence of certain crimes, notably violent robberies in and around the metropolis of London. In the second half of 1744 the London 
newspapers showed a growing interest in the crime of street robbery. They reported in great depth upon the apprehension of some notorious street robbers linked to known gangs. While this moral panic possibly resulted from growing criminality, it may also be attributed to an editorial need for sensational news due to a dearth in noteworthy foreign war reports. ${ }^{4}$ In contrast, the same moral panic over crime was not evident in the Scottish newspapers. When reporting upon the conviction and execution of John Irving in Edinburgh, after he had robbed two different people upon the highways in September 1744, the Caledonian Mercury provided only the basic details of the case and neglected to include that he had also shot one of his victims. ${ }^{5}$ Further anxieties over robbery in England were heightened in the aftermath of the War of the Austrian Succession and the early 1750s saw commentators proposing a variety of measures to stem the feared crime epidemic. ${ }^{6}$ The House of Commons committee appointed in February 1751 to investigate the existing laws related to offences against the peace included the Prime Minister, Henry Pelham, and the Secretary of War, Henry Fox, but also all Members of Parliament for London and the counties of Middlesex and Surrey, perhaps reflecting that the problem was very much believed to be centred upon London. ${ }^{7}$

Comparatively, in mid-eighteenth-century Scotland the increased use of the death sentence and the more intense debates over capital punishment in public discourse were not associated with fears over crime in the more metropolitan centre. Instead, a crucial explanation for the increase in the sheer number of executions as well as a more marked determination to send offenders to the gallows was the aftermath of the 1745 Jacobite Rebellion and the desire to establish lasting stability in the peripheral north. Between 1746 and 1755 there were a total of 75 executions carried out in Scotland; 26 for murder, 46 for property offences and a further three for crimes categorised in Table 2.5 as 'other', namely rape and bestiality. Table 2.6 demonstrates that the 1740s and 1750s saw around $80 \%$ of those capitally convicted subsequently executed, a level not reached again even during the increased numbers of executions in the 1780s and the early nineteenth century. A large proportion, 43 of the total 75 executions, followed trials before the Northern Circuit compared with only 15 from the High Court in Edinburgh and even fewer numbers from the other circuits. Therefore, while acknowledging that Scotland was not alone in experiencing an increase in capital convictions in this period, the chapter will demontrate that the reasons for this were different from the situation in England, being largely linked to the aftermath of the late 1745 Jacobite Rebellion. 
In April 1746, the Jacobite army was decisively defeated at the Battle of Culloden and the circuit courts resumed business after some disruptions, particularly in the Northern Circuit. The government army, under the leadership of the Duke of Cumberland, sought to hunt down any remaining rebels and permanently suppress any potential future unrest. Key themes to emerge from a study of the ' 45 and the Hanoverian government's response to it are those concerning 'Britishness', 'savagery' and the quest to 'civilise' the Scottish Highlands. In his study of the suppression of the rebellion, Plank focused upon the use of the army as an agent for social progress in Britain and the colonies. In dissecting the concepts of 'rebellion' and 'savagery' he made the distinction that those engaged in a rebellion had a personal responsibility and were thus tried and convicted for it. By contrast, the term savagery was a characteristic applied to whole communities, in this case the Highlands, who could be 'corrected' through a policy of expulsion or punitive action. ${ }^{8}$ These distinctions were significant in dictating the punishments meted out to the rebels, which will be briefly discussed in Chap. 5 , and in gaining an understanding of the army's relations with the non-combatants in the Highlands immediately following Culloden. However, this chapter will demonstrate that the suspicion and disdain that had typified English and Lowland Scottish views of the Highlands during the rebellion continued in its wake. In turn, the desire to establish permanent stability in the area greatly impacted upon the Northern Circuit court's use of the death sentence.

The acknowledgement of the need for a tighter control of the Highlands was not new in the mid-eighteenth century. Following the 1715 Jacobite Rebellion there were some who believed that the state had not punished the disaffected areas harshly enough, which had led to further unrest in $1745 . .^{9}$ Disarming acts in 1716 and 1725 had attempted to legislate against the possession of weapons such as broadswords and various guns in northern Scotland. Under the leadership of General Wade, 260 miles of roads had been constructed along the Great Glen linking Inverness to the western seaboard at Fort William and linking the Lowlands to the Great Glen. ${ }^{10}$ Following the defeat of the '45, a further Disarming Act was passed in 1746 as well as legislation banning the wearing of Highland dress such as tartan and kilts (19 Geo II c.39). In addition, there was a contemporary belief that heritable judicial powers had been crucial in helping Highland Clan Chiefs to raise support for the rebellion and thus there was a need to curb these powers to secure future stability in the area. ${ }^{11}$ The Heritable Jurisdictions (Scotland) Act was 
duly passed in 1747. Davies has demonstrated that the act was not revolutionary in the sense that it was the conclusion to a longer-term decline of the old Scottish legal order and thus the heritable powers it abolished had already declined by the mid-eighteenth century. ${ }^{12}$ However, for the purposes of this study, its passing can be contextualised within wider attempts to suppress the very Highland culture that was believed to have fostered unrest and encouraged rebellion.

In several of the 75 executions carried out in Scotland in the decade following the ' 45 , including some of those following trials before the Northern Circuit, the circumstances surrounding the cases and the judicial responses to them were comparable to several others that occurred across the period between the mid-eighteenth and early nineteenth centuries. Among the malefactors sent to the gallows were infanticidal mothers, murderous husbands and property offenders found guilty of robberies, housebreakings and thefts. However, the focus here is to demonstrate that a marked proportion of the executions that followed trials before the Northern Circuit in this ten-year period can be explicitly linked to the aftermath of the ' 45 and the wider attempts to suppress the perceived lawlessness of the Highlands. For example, Alexander Cheyne's case in 1748 stood out from those of the other robbers who faced the hangman's noose in the mid-eighteenth century as the court heard how he was a person of 'bad repute' who was known to keep company with the worst kind of rogues and thieves in the area. He had also been outlawed for failing to appear to answer for previous crimes. ${ }^{13}$ Similarly, in the same year James Davidson, along with unidentified accomplices, broke into the home of Robert Paton and threatened his family with broadswords and pistols, weapons banned by the recent legislation, and stole a quantity of money. He was executed and hung in chains on the road leading into Aberdeen. ${ }^{14}$ His case is detailed further in Chap. 7 and was one of a number where it was deemed necessary to make an exemplary display of national justice at a local level.

Cattle theft by large groups in the Scottish Highlands had been a problem prior to the mid-eighteenth century and was particularly prominent in the western Highland area of Lochaber. Cattle were the main source of wealth in the area but, following the rebellion, herds were confiscated on a large scale, even from some of the people who had been loyal to the government. For a time, Fort Augustus became the largest cattle market in Scotland, partly due to a steady supply of confiscations. ${ }^{15}$ In the period 1746 to 1755 there were 16 executions 
for cattle or horse theft, only two of which occurred outside of the Northern Circuit. Although the trials were held in Inverness, Perth and Aberdeen the places where the thefts were stated to have taken place show that the crime was not only committed in the immediate vicinity of these larger cities but was apparent across various areas of northern Scotland, both east and west. Within the large body of correspondence between government and army officials in Scotland and authorities in London in the years immediately following the ' 45 , the problem of cattle and horse theft was highlighted. In a letter to the Duke of Argyle, on behalf of several of his tenants in Morvern, John McDougall complained of the thefts. Morvern is a peninsula in south-west Lochaber but he claimed that the people there had no affiliation with Clan Cameron whose relations he accused of being principally concerned in the crime. He informed the Duke that several of the tenants had taken to guarding their livestock continually and needed more government protection. ${ }^{16}$

The aftermath of the ' 45 , and the rigour with which instances of cattle theft were pursued by the authorities, is perhaps reflective of the fact that the crime had been a long-standing feature in parts of northern Scotland, and that the government believed it had not been adequately punished. This could, in part, have been due to the lack of sufficient central judicial power in the area. In his 1724 investigation of the Highlands, General Wade found the widespread practice of blackmailing for 'protection' which was largely centred upon the theft of black cattle. ${ }^{17}$ Barrie and Broomhall argued that, with the exception of the larger burghs, many Scottish communities were isolated which made gaining access to fiscals, magistrates and legal courts difficult and potentially costly. ${ }^{18}$ The perpetuation of the offence was therefore likely facilitated by wider issues surrounding crime detection, reporting and prosecution, especially in peripheral areas that were separated geographically, and perhaps ideologically and even, to some extent, linguistically, from the country's centre. For example, there were some instances where translation into Gaelic was required in the courts for the accused, the victim and/or the witnesses in some cases. However, consideration must also be given to the distinct and long-standing customary attitudes and responses to the crime that may have prevented those suspected being brought before the central criminal courts. In almost all the cases brought before the Northern Circuit between 1746 and 1755 the panel (the accused) was not only charged with a specific instance of theft/s. Instead, the charge would also state that they were 'habute' thieves as an aggravation to their crime. Kenneth Dow Kennedy was accused of having been a notorious 
cattle thief for upwards of 20 years during his trial in $1750 .{ }^{19}$ The fact that Kennedy and others had been able to carry on their crimes for years seemingly unchecked suggests that customary practices in certain areas of northern Scotland meant that there was either some reluctance or an inability for victims to prosecute the crimes in the central courts.

King and Ward have identified the "widespread reluctance of many areas on the periphery" to implement capital punishments for property offences in the eighteenth century. ${ }^{20}$ In addition, Howard has demonstrated that legal officials took only a limited role in the investigation of theft in Wales and that it was often a matter of private initiative wherein some sort of restorative action, such as the returning of property or the paying of compensation, was preferred to the pursuing of punitive justice. ${ }^{21}$ In the Scottish court records, a reading of some of the witness statements does highlight that in cases where the accused had been 'habute' thieves, the victims had previously taken it upon themselves to pursue the offender and take back their property without going through the courts. Therefore, in parts of northern Scotland it is likely that the reporting and pursuing of cattle thieves was subject to extra-judicial discretion but was also made more difficult as it was such a common feature of certain areas. When John Breck MacMillan mounted the scaffold in Inverlochy in 1755 the recorder of his speech observed that theft of cattle was "not reckoned too dishonourable by the commonality in that part of the world as in other places." 22 However, in the wake of the ' 45 , the authorities sought to curb these practices. The decision to execute offenders at spatially significant locations reflected the need to emphasise the infamy of the criminal in addition to making the punishment highly visible at a local level.

Twelve people were sentenced to be executed either at the scene of their crime or within the town in which it was committed between 1740 and 1755. Ten of the cases were convicted before the Northern Circuit and eight of these were for property offences. This was an evident concentration of the punishment as between 1740 and 1799 there were only 21 people executed at the scene of their crime and it was not until the increasing numbers of executions at the beginning of the nineteenth century that a marked increase in crime scene executions would occur again. In five of the cases the criminals had been condemned at Inverness for cattle theft and were sentenced to be taken to Fort William to be confined before their execution in Inverlochy. Fort William is in Lochaber and in the eighteenth century was one of three Great Glen fortifications along with Fort Augustus and Fort George. During the '45 it was the only one of the three not to fall into the hands of the rebel 
army and following the rebellion it remained a government army base. Donald McOiloig (alias Cameron), also commonly called 'the Officer', was described in court as a most notorious cattle thief who had been so for 20 years. He had been apprehended by a party of General Pultney's regiment and sent to Inverness for trial before the circuit court and was sentenced to be executed in Inverlochy in $1752 .{ }^{23} \mathrm{He}$ was executed at the Old Castle of Inverlochy, a mile north of Fort William, a location chosen as it was not only geographically close to the fort but also because the area was a centre of Clan Cameron, his relations and kinsmen, and thus had more potential punitive value than execution at the common place in Inverness. A report of his execution praised the pains taken by the troops in the Highlands to apprehend the "great numbers of these villains" in the area and hoped the success they achieved would finally put an end to the "wicked practice." 24 Crime scene executions for cattle theft were not only reserved for Inverlochy. Donald Bain was condemned at Perth for multiple instances of cattle and horse theft in the area surrounding Kinloch Rannoch. Witnesses told the court how he dressed in full Highland plaid when committing the crimes and had attempted to charge them for the return of their property. He was executed in the same village on a "conspicuous eminence" in August 1753, likely in front of several of those he had stolen from and intimidated, which again potentially added further punitive weight to the spectacle. ${ }^{25}$

\section{Capital Punishment in the 1780s and the Crisis of Transportation in Scotland}

Following the mid-eighteenth-century peak, the number of executions in Scotland declined in the late 1750s and remained relatively stable throughout the 1760s and 1770s. However, Table 2.1 demonstrates that the number of executions in the 1780s more than doubled compared to the previous decade, with 79 offenders suffering the death sentence. Although the mid-eighteenth century witnessed intensified concerns over crime both north and south of the border, the spike in the number of executions in Scotland had marked links to the aftermath of the 1745 Jacobite Rebellion and the desire to establish control over the peripheral north. This section will demonstrate that the cause of the peak number of executions in the 1780s can be placed more squarely within the wider British context due to Britain's involvement in the American War of Independence (1775-1783). First, the demobilisation of large numbers of the armed forces following major wars had been 
cause for concern earlier in the eighteenth century in England, but had not been an evident concern in Scotland. However, following the War of Independence, a marked proportion of offenders were stated to have either been late soldiers and sailors or part of army regiments billeted in Edinburgh, Glasgow and Inverness. Second, the conflict caused severe disruption to, and the eventual removal of, the penal option for Britain to transport her criminals to the American colonies. In addition, the alternative destination of Botany Bay was not immediately established and the First Fleet did not embark until 1787. The temporary cessation of transportation greatly impacted upon the Scottish courts' ability to exercise discretion in potentially capital cases and is thus crucial to our understanding of the peak numbers of malefactors facing the death sentence in Scotland in this period.

This section focuses upon the period between 1780 and 1789 . Although the outbreak of the War of Independence in 1775 had affected Britain's ability to transport its felons in the late 1770s, the impact on the levels of capital punishment in Scotland did not become more evident until the turn of the 1780s. ${ }^{26}$ There were large numbers of offenders still awaiting sentences of transportation that had been passed after 1775 in the Scottish places of confinement and it became increasingly apparent in the courts that this form of punishment could not be sustained. The nuances of the Scottish system, detailed in Chap. 2, relied heavily upon the availability of suitably severe secondary punishments that fell short of death. Banishment from Scotland was still a frequently used punishment in this period and sentences of imprisonment increased in the late eighteenth century. However, the removal of the penal option of transportation posed a significant problem. This was of crucial importance to the punishment of property offences as it greatly impacted upon the courts' ability to restrict the level of punishment to be meted out to those brought before them. When breaking down the executions in this ten-year period into category of offence, Table 2.5 demonstrates that $92.4 \%$ of the total 79 convicted persons had committed a property crime. This represents the highest proportion of the total executions accounted for by property offences across the entire century under examination in this study.

Within studies of capital punishment in eighteenth-century England, the 1780s have been marked out as a focal period in the country's use of the death sentence. Beattie's figures showed that there was an increase in capital convictions and executions in England after 1782 and that in Surrey there were more offenders executed in the year 1785 than in any 
other in the second half of the eighteenth century. ${ }^{27}$ From September 1782 the government was determined that no one convicted at the Old Bailey of robberies or burglaries that included any degree of violence would be pardoned. In addition, Devereaux has shown that between 1775 and 1779 there was an average of 34 executions per year in London but the figure rose to 47 between 1780 and 1784 and to nearly 80 by the mid-1780s before dramatically retreating. ${ }^{28}$ Comparatively, although the sheer number of executions in the 1780s had doubled compared to the previous decade, there was not the same evident desire in Scotland, as there had been in the mid-eighteenth century, to see a large proportion of capitally convicted offenders hang for their crimes. This is evidenced by the fact that $64.8 \%$ of the total capitally convicted criminals were executed in the 1770 s and the figure rose only slightly to $65.8 \%$ in the $1780 \mathrm{~s}$.

In times of war, large numbers of young men were sent abroad, thus helping to drain some of the labour surplus in major cities and producing work for those who were left. However, as peace was achieved and armed forces returned home, levels of property crime increased. Hay stated that the greatest pressure on the poor could be expected when a dearth in food supply and demobilisation coincided. This occurred in England in 1783 and Hay estimated that $20 \%$ of the population were destitute and, at the same time, the second largest army of the eighteenth century was paid off. In turn, this year saw the greatest percentage increase in indictments for theft in Staffordshire and the Home Counties. ${ }^{29}$ Similarly, Beattie demonstrated that, compared to the period 1776 to 1782 , when $29(31.2 \%)$ of 93 people sentenced to death were executed in Surrey, the period 1783 to 1787 saw $64(49.2 \%)$ of 130 people capitally convicted executed. This was an average of 12.8 executions per year which fell to 5.3 after 1788 , the year associated with recruitment for the French Revolutionary Wars. ${ }^{30}$ Unlike the earlier fears of crime and demobilisation that had occurred in England in the mid-eighteenth century but were not as evident in Scotland, the drivers behind the 1780s increase in capital convictions were more comparable.

After the 1707 Union, the Scottish army and navy merged with those of England to form the new British Army. From the mid-eighteenth century, the army began to increasingly recruit for Scottish regiments such as the Scots Guards but also a newer regiment of Highlanders. During the major wars of the second half of the eighteenth century the Scots played an influential role in the British army. ${ }^{31}$ In the 1780 s, following 
the American War of Independence, soldiers made up a notable proportion of the increased numbers of capital convictions, especially those billeted in Edinburgh and Glasgow. Of 120 capital convictions between 1780 and 1789,19 offenders $(15.8 \%)$ were stated to have been members of the army or the navy and 17 of these occurred after the war's end in 1783. The convictions were all for property offences; 12 robberies, six instances of house or shop breaking and theft, and one case of forgery. Following these convictions, there were ten executions and nine remissions. Interestingly, in three of the remissions the condition stipulated was that the pardoned person would enter the armed forces and in a further four they were to be set at liberty. Presumably, under both circumstances the men would have re-joined their regiment. An example of this was the case of James McMoin who had been condemned at Glasgow for robbery. He had committed the crime with three of his fellow soldiers but was believed to be the principal actor. He had already been taken before a court martial and received part of a sentence of 800 lashes. Following his capital conviction before the circuit court, mercy had been recommended. ${ }^{32}$

The outbreak of the War of Independence resulted in the end of the penal option of transporting criminals to the American colonies. Convict transportation to Australia did not immediately become an alternative destination as the First Fleet did not embark until 1787. Donnachie stated that, prior to the 1780 s, transportation had been used relatively infrequently by the Scots. Even after the establishment of transportation to Australia he estimated that the Scots made up just over 5\% of the convicts sent from Britain and Ireland. ${ }^{33}$ However, this seemingly low proportion of offenders is arguably more reflective of the lower numbers tried by the Scottish courts for capital or transportable offences rather than an aversion to the use of the punishment. In Scotland, the temporary cessation of the penal option of transportation did have a marked effect upon levels of capital punishment which provides strong evidence of the centrality of the punishment within the arsenal of the Scottish courts. The courts continued to sentence the punishment even after the outbreak of the war in 1775, which meant that the places of confinement were filled with offenders waiting to be sent to London. However, by the turn of the 1780s there was an evident decrease of the sentence, perhaps due to the realisation that the places of confinement were already under pressure from offenders awaiting transportation. The courts' sentencing of transportation would not increase again until well into the 1790s. 
Therefore, the need for alternative punishments that fell short of the severity of the death sentence in the 1780s led to an increase in banishment from Scotland as well as a less dramatic increase in prison sentences for some property offences that would have most likely carried a sentence of transportation previously. Similar problems were facing the authorities in England and in 1786 the Gentleman's Magazine included a petition sent to the king from the Lord Mayor and Aldermen of the City of London. They complained of the interruption to transportation and the fact that more convicts, who were supposed to be sent abroad, were either at large or confined in prisons. They blamed this "dreadful accumulation" for the increase in crime "so heavily felt and so justly complained of." 34

In the 1780s there were 79 offenders executed in Scotland. In 73 $(92.4 \%)$ of the cases they had been convicted of a property offence. This was the highest percentage of the total executions made up by property offenders across the period 1740 to 1834 . Housebreaking and theft accounted for 34 of the total 79 executions. In the 1770s the crime made up only $17 \%$ of the total executions compared to $43 \%$ in this tenyear period before it fell to $12.5 \%$ in the 1790 s. A reading of the petitions for mercy sent to London highlighted that there was some debate over the severity of the death sentence for certain property offences. In the case of James Grant, he was found guilty of housebreaking and theft but, on account of "several alleviating circumstances", he was recommended mercy. ${ }^{35}$ These circumstances were that he had returned the stolen property and had made a full confession to the court. However, petitions from the judges Hallies and Erkgrove as well as from the magistrates of Aberdeen and members of Marischal College, failed to secure him a pardon. ${ }^{36}$ In 1783 Alexander Mowat's defence claimed that he had committed a single act of housebreaking and theft with no aggravations and called for the charge to be restricted so he would not face the death sentence. However, the Advocate Depute answered that a single theft was capital in Scotland as in England. ${ }^{37}$ It can be argued that, had the secondary punishment of transportation been a viable option, the charge would have been restricted prior to the start of the trial, as was the precedent in so many other cases of housebreaking and theft across this period, so he would have faced a sufficiently severe punishment that fell short of death.

In terms of other property offences, executions for cattle, horse or sheep theft witnessed a slight increase in the 1780s after they had gradually decreased in the 1760s and 1770s. In addition, executions for robbery increased from eight in the 1770s to 14 in the 1780s. However, 
proportionately the percentage they made up of the total executions fell from $23 \%$ in the 1770 s to $18 \%$ in the 1780 s, arguably due to the increased executions for housebreaking and theft. As offenders accused of robbery were less likely to be able to petition the court or have their charge and punishment restricted prior to the start of their trial, the limited availability of transportation did not have the same effect of increasing the number of executions for the crime as it did for housebreaking and theft. However, in the case of James Andrew, it may have gone some way to preventing him obtaining a conditional pardon. He was condemned in Edinburgh in February 1784 for robbing John Dykes of a silver watch in Hope Park. The jury had strongly recommended mercy due to his relatively young age of 21 and possibly as the robbery had not involved any great degree of violence against the victim. ${ }^{38}$ When reporting upon his execution the Caledonian Mercury stated that they could not fail to mention "to the honour of the magistrates, and as an instance of real humanity, that the execution was delayed considerably beyond the usual time in hopes of a reprieve being received." 39

The desire for mercy to be shown, at least at a more local level, was also evident in various petitions sent to London in this period. William Tough was charged with housebreaking and theft before the circuit court in Aberdeen and despite the removal of part of the charge in the libel, in order to mitigate his case, he was sentenced to death in October 1788.40 The subscribers of a petition sent from Aberdeen to London offered to pay the expenses of having him sent abroad instead. ${ }^{41}$ Although this offer does not appear to have been taken up, his execution was delayed and he was pardoned in March 1789 on condition of transportation. Jean Craig was one of seven women capitally punished between 1780 and 1789. She had stolen from a bleaching field in 1784 and was executed in Aberdeen. A petition from John Grieve, an official in Aberdeen, had been sent to the Lord Advocate asking him to support it when it was sent to London. He emphasised that there was already another woman in Aberdeen under sentence of death, Elspeth Reid, for housebreaking and theft, and stated "I would fain hope that the execution of one might somewhat suffice the public." 42 As Chap. 4 will demonstrate, women across the entire period 1740 to 1834 were predominantly executed for murder. However, in the 1780s seven women were executed for property offences and, while most of their cases were aggravated by their being found to be 'habute' thieves, we can question if at least some of 
them would have been remitted on condition of transportation if it had been an available option.

In addition to an analysis of those executed following the passing of the death sentence, it is now beneficial to turn to an investigation of the 41 people who received a pardon in the 1780s. Table 2.9 demonstrates that $39(95.2 \%)$ of these remissions were for property offences. This figure presented the highest proportion of remissions for property offences across the entire period under investigation in this study. Of the total pardons, 24 were on condition of transportation, two on condition of banishment, seven were to be set at liberty and eight were pardoned on condition of entering either the army or the sea services; seven of these eight cases occurred in 1780-1781, during the latter years of the American War of Independence. A recurring argument for mercy was the youth of the condemned as the predominant age range of those condemned for property offences was between 20 and 24. In his investigation of the age of offenders charged with the crimes of burglary and housebreaking before the English Home Circuit between 1782 and 1800 , King highlighted the similarly large proportion of offenders that were aged between 17 and $26 .^{43}$

Robert Ligget, age 20, and John Carmichael, age 23, had been condemned in Dumfries for housebreaking and theft in which they stole six gallons of spirits. In a letter to the Home Office, one of the judges, who was also the Lord Justice Clerk, Robert Macqueen, Lord Braxfield, stated that the crime was certainly capital yet the jury had recommended them to mercy due to their age. He added that if His Majesty wanted to extend mercy it should only be to Ligget as the younger of the two. ${ }^{44}$ Similarly, following the conviction of Henrietta Faulds in 1784, a petition sent from Glasgow stated that thousands of its inhabitants wished for the extension of mercy. A further petition had begged for the assistance of the Lord Advocate in securing a pardon and having it sent express to Glasgow at the town's expense. ${ }^{45}$ She was eventually pardoned on condition of banishment. Furthermore, in at least six cases where the condemned had been remitted on condition of transportation they subsequently received further remissions of this sentence between 1787 and 1789 and instead were banished or set at liberty. It is evident that there were similar drivers behind the increased use of the death sentence north and south of the border in the 1780s. However, again, an exploration of the Scottish response adds a further dynamic to our understanding of the period as, despite an increase in the sheer number of capital convictions, there was not the same desire, especially within local areas, to 
send a large proportion of capitally convicted offenders to the scaffold as appeared to be the case in London and the Home Counties.

\section{Executions in Early Nineteenth-Century Scotland}

The first third of the nineteenth century was a period of discussion and debate over the use of the death sentence and the merits of public punishment. As in the previous peak periods of execution discussed above, we can draw notable comparisons between the use of capital punishment in Scotland and in England. Numbers of capital convictions increased both north and south of the border, in Scotland to unprecedented levels, and, in both countries, debates over the use of the scaffold permeated public discourse. In turn, by the 1830s the number of executions decreased and in both countries the death sentence was predominantly only used for the crime of murder as property offenders were increasingly sentenced to the secondary punishments of transportation or imprisonment. What is clear is that the early nineteenth century was a focal period in Britain's capital punishment history. While England's use of the death sentence has been subject to rich historical analysis, there is a relative dearth in studies examining the Scottish experience of capital punishment in this period. ${ }^{46}$ There have been quantitative surveys of Scottish crime using the parliamentary returns, which are more regularly available for the period after 1836, that have highlighted an increase in recorded and prosecuted crime. ${ }^{47}$ However, the current study is the first to provide an extensive examination of Scotland's capital punishment history in this period, including an analysis of the factors that impacted upon the use of the death sentence. While a study of the Scottish experience offers notable comparisons and reinforcements to studies of England, it cannot simply be assimilated into this more developed historical field. Instead, a study of Scotland's distinct response to the increase in the number of offenders facing the hangman's noose provides a rethinking of the wider British capital punishment narrative in the early nineteenth century.

Table 2.1 demonstrates that in the second decade of the nineteenth century the number of executions in Scotland doubled compared to the previous decade. Furthermore, unlike the subsequent reduction in the number that was evident following earlier peak decades of executions, the 1820s saw a further increase. When demonstrating the pattern of capital convictions and executions in England, Emsley showed that for London and Middlesex capital convictions markedly increased following 
the end of the Napoleonic Wars but the number of executions did not drastically increase. He argued that this widening gap between capital convictions and executions, while coming at a time when the 'Bloody Code' faced increasing criticism by reformers, may also have been recognition, on the part of the authorities, that it would not be acceptable to execute so many individuals. ${ }^{48}$ In a similar vein, Gatrell highlighted that in 1785 , during the crime wave of the 1780s, of the 153 criminals capitally convicted at the Old Bailey, 85 were executed. He argued that, while it may have been plausible to execute $56 \%$ of the total offenders capitally convicted in 1785 , by the 1820 s this proportion could not be sustained. ${ }^{49}$ Thus he cited the rising death sentences of the early nineteenth century as a primary reason why "the system unravelled itself and became unworkable." 50

Comparatively, Table 2.6 shows that in Scotland the proportion of offenders capitally convicted who were subsequently executed was consistently $60 \%$ or more by the 1770 s and, if we remove the numbers of those executed and remitted for treason, the figure was still $52 \%$ in the $1820 \mathrm{~s} .{ }^{51}$ A potential explanation for this proportional continuity may be found in a reading of judicial opinion when sentencing offenders. The current study provides a reinforcement of the argument briefly made by Crowther, namely that in Scotland, rather than keeping executions to a socially acceptable level in the early nineteenth century, as Gatrell's argument suggested, the unprecedented number of capital convictions meant that it was believed to be necessary to keep up the level of exemplary punishments. ${ }^{52}$ To advance this argument, this chapter will now turn to investigate the factors that contributed to both the increased levels of capital convictions and the continuity in the proportion executed.

The increase and density of population growth across Scotland's central belt was a key factor that contributed to the increased proportion of capital convictions and resulting executions in the area. However, it will be demonstrated that, while the numbers of people executed increased in Edinburgh, the number per 100,000 head of Scotland's population did not witness the same increase evident in the figure for the Western Circuit which covered an area that had experienced rapid population growth. As an example, Table 2.4 shows that in Edinburgh executions per 100,000 head of Scotland's population remained between 1.1 and 1.7 across the period from the mid-eighteenth century to the late 1820 s. It was similarly the case in the Southern and Northern Circuits, after the mid-eighteenth-century peak, with both having consistently low figures 
below 1.0. However, the figure for the Western Circuit rose from 0.2 in the mid-eighteenth century to 1.7 by the $1820 \mathrm{~s}$, with an increase of 0.5 occurring between 1810 and 1829 . When we break down the figures for the Western Circuit it is evident that property offences accounted for much of this increase.

Glasgow's population had risen from 32,000 in 1755 to 147,000 in 1821 and the accompanying industrial growth and urbanisation has been described as a "cumulative and self-reinforcing growth that produced the greatest of Britain's provincial cities." 53 When investigating the industrialisation and demographic change in Glasgow in the first half of the nineteenth century, Gibb pointed towards rapid urbanisation due to population growth and migration from other areas of Scotland as well as from Ireland. Furthermore, he highlighted that between 1814 and 1830 the living standards of the unskilled workforce fell markedly in the face of over-crowding and inadequate nourishment. ${ }^{54}$ Lenman noted that the Napoleonic wartime levels of income for handloom weavers, particularly those working on the plainer fabrics that accounted for the majority of their production, fell sharply after 1815 and did not recover. ${ }^{55}$ In addition, Barrie and Broomhall argued that it was in expanding towns such as Glasgow that discontent was expressed by the middling ranks over the level of protection offered to property and that these concerns were key in the push for the establishment of police courts. ${ }^{56}$ Although the jurisdiction of police courts was limited to minor offences, and the punishments they meted out were limited to short-term prison sentences and fines, the desire for more speed and efficiency in prosecuting offenders is perhaps reflective of broader concerns over the believed prevalence of property crime.

In terms of the infliction of capital punishment, the number of people executed for property offences in Glasgow equalled and then surpassed the figure for Edinburgh. In their recent study of the regional variations in the implementation of capital punishment for property offences in the third quarter of the eighteenth century, King and Ward argued that executions for property offences were markedly higher in and around the central urban areas than on the peripheries in Britain. ${ }^{57}$ The mid-eighteenth-century peak in executions provides a caveat to their findings, as capital punishment was used to further punish the peripheral north. However, an analysis of the early nineteenth century provides a reinforcement of their centre-periphery dichotomy. Despite covering roughly one seventh of the geographical area of Scotland, the central belt 
contained the highest density of population and industry and the area accounted for the highest proportion of executions for property offences.

Of the total capital convictions following trials before the Western Circuit between 1810 and $1819,36(92 \%)$ were for property offences and between 1820 and 1829 the figure was 46 (88.5\%). Table 2.8 shows the proportion of those capitally convicted for property offences executed in Scotland. The 1820s evidently witnessed the lowest percentage of convicted property offenders sent to the gallows despite the decade having the highest number of capital convictions. In Edinburgh, of 36 capital convictions for property offences between 1810 and 1819, $26(72.2 \%)$ were executed. However, of 42 capital convictions in the 1820 s only 14 $(33.3 \%)$ were executed. This pattern fits with the arguments of Gatrell and Emsley discussed above, namely that in the face of rising capital convictions, the proportion of offenders who were executed fell, particularly for certain property offences. However, the figures for the Western Circuit do not support this argument and provide a notable caveat as they were markedly higher with $55.6 \%$ of capitally convicted property offenders executed between 1810 and 1819 and $63 \%$ in the 1820 s. Table 3.1, showing executions for property offences per 100,000 head of Scotland's population by circuit, shows that by the early nineteenth century the figure for the Western Circuit, notably Glasgow, equalled and then surpassed that for Edinburgh. In contrast, the figures presented in

Table 3.1 Executions for property offences per 100,000 head of Scotland's population

\begin{tabular}{|c|c|c|c|c|c|c|c|c|c|c|}
\hline & \multicolumn{2}{|c|}{ Total } & \multicolumn{2}{|c|}{ Edinburgh } & \multicolumn{2}{|c|}{ Northern } & \multicolumn{2}{|c|}{ Western } & \multicolumn{2}{|c|}{ Southern } \\
\hline & Ex. & $\begin{array}{l}\text { Per } \\
\text { head of } \\
\text { pop. }\end{array}$ & $E x$. & $\begin{array}{l}\text { Per } \\
\text { head of } \\
\text { pop. }\end{array}$ & $E x$. & $\begin{array}{l}\text { Per } \\
\text { head of } \\
\text { pop. }\end{array}$ & $E x$. & $\begin{array}{l}\text { Per } \\
\text { head } \\
\text { of pop. }\end{array}$ & $E x$. & $\begin{array}{l}\text { Per head } \\
\text { of pop. }\end{array}$ \\
\hline $1750-1759$ & $39^{a}$ & 3.1 & 6 & 0.5 & 27 & 2.1 & 2 & 0.2 & 4 & 0.3 \\
\hline 1800-1809 & 22 & 1.7 & 10 & 0.6 & 3 & 0.2 & 6 & 0.4 & 3 & 0.2 \\
\hline 1810-1819 & 59 & 3.7 & 26 & 1.4 & 5 & 0.3 & 20 & 1.1 & 8 & 0.4 \\
\hline $1820-1829$ & 52 & 2.5 & 14 & 0.7 & 4 & 0.2 & 29 & 1.4 & 5 & 0.2 \\
\hline
\end{tabular}

${ }^{a}$ Note there were an additional four executions as a result of trials before the sheriffs in the 1750s which makes the total Fig. 43. However, these additional cases are not included here as they were conducted in various areas.

Source Figures compiled using Justiciary Court records and population statistics provided in Kyd, Scottish Population Statistics, p. xvii and the Enumeration of the Inhabitants of Scotland (Glasgow: 1823). 
Table 3.2 for murder in the Western Circuit remained very low at 0.1, behind that of Edinburgh and the Northern Circuit.

A key source utilised to gain a degree of understanding of crime, or more specifically the believed prevalence of crime, in this period is the newspapers. Until the late eighteenth century, with the exception of reporting upon certain executions in northern Scotland in the post-1745 decade, crime reporting in the Scottish newspapers often only contained the basic facts of the offence with little of the journalistic opinion that can be found in the London newspapers. However, by the early nineteenth century, the newspapers offered a greater volume of opinion regarding the need for exemplary punishment in the face of a believed rise in crime. Kilday argued that in this period the newspapers gave an alarming impression regarding the nature and frequency of crime, even though the sheer number of indictments remained lower than in other countries. She suggested that this distortion played a key part in the "burgeoning misconception surrounding Scottish crime." 58 From a reading of the newspapers it is evident that, despite the reporting of increased numbers sent to the scaffold, there was an acknowledgement that Scotland was not the forerunner in this trend. However, crucially, it is also evident that certain crimes were portrayed as being committed on an unprecedented level due to the numbers being sent to the gallows. Reporting on the case of two men executed for robbery in 1815 the Scots Magazine echoed the sentiment of the Lord Justice Clerk in passing the death sentence, namely that the most vigorous administration of justice was required to curb the crime which was "unknown formerly in this part of the United Kingdom." 59

Table 3.2 Executions for murder per 100,000 head of Scotland's population

\begin{tabular}{|c|c|c|c|c|c|c|c|c|c|c|}
\hline & \multicolumn{2}{|c|}{ Total } & \multicolumn{2}{|c|}{ Edinburgh } & \multicolumn{2}{|c|}{ Northern } & \multicolumn{2}{|c|}{ Western } & \multicolumn{2}{|c|}{ Southern } \\
\hline & $E x$. & $\begin{array}{l}\text { Per } \\
\text { head of } \\
\text { pop. }\end{array}$ & $E x$ & $\begin{array}{l}\text { Per } \\
\text { head } \\
\text { of pop. }\end{array}$ & $E x$ & $\begin{array}{l}\text { Per } \\
\text { head of } \\
\text { pop. }\end{array}$ & $E x$ & $\begin{array}{l}\text { Per } \\
\text { head of } \\
\text { pop. }\end{array}$ & $E x$ & $\begin{array}{l}\text { Per head } \\
\text { of pop. }\end{array}$ \\
\hline $1750-1759$ & 22 & 1.7 & 8 & 0.6 & 10 & 0.8 & 1 & 0.08 & 3 & 0.2 \\
\hline 1800-1809 & 14 & 0.9 & 7 & 0.4 & 3 & 0.2 & 3 & 0.2 & 1 & 0.06 \\
\hline $1810-1819$ & 13 & 0.7 & 5 & 0.3 & 3 & 0.2 & 2 & 0.1 & 3 & 0.2 \\
\hline $1820-1829$ & 25 & 1.2 & 14 & 0.7 & 6 & 0.3 & 3 & 0.1 & 2 & 0.09 \\
\hline
\end{tabular}

Source Figures compiled using Justiciary Court records and population statistics provided in Kyd, Scottish Population Statistics, p. xvii and the Enumeration of the Inhabitants of Scotland (Glasgow: 1823) 
A recurring theme and contemporary fear expressed in the court records, but even more so in the newspapers, was the youth of many of those receiving capital punishments. In October 1817 the Scots Magazine commented that it was a remarkable circumstance and a deep regret that in one month it had been necessary to execute 11 people and most were under the age of $30 .{ }^{60}$ Using the enumeration statistics available for 1821 it is possible to calculate that in most areas, including the main cities of Edinburgh, Inverness and Aberdeen, the industrial areas in and around Lanark, which included Glasgow, and large areas of northern Scotland including Caithness, Ross and Cromarty, about a quarter of the male population was aged between 15 and 30 with a further 9-13\% aged between 30 and $40 .{ }^{61}$ Of the 154 people executed in Scotland between 1810 and 1829 , it is possible to calculate from the ages provided that at least $60 \%$ were aged between 15 and 25 and a further $12 \%$ were aged between 26 and 30. In March 1812 Hugh MacDonald, Neil Sutherland and Hugh Mackintosh were indicted for several robberies, with Mackintosh additionally charged with murder. The crimes were part of riots that had occurred in Edinburgh in December 1811, in which "idle apprentice boys ... knocked down, robbed and wantonly abused almost every person who had the misfortune to fall in their way." Amidst attempts to quell the unrest Dugald Campbell, a police watchman, was beaten to death. The magistrates of the city offered monetary rewards for the apprehension of the culprits, especially the murderer. Of the arrests made, five men were brought to trial with others acting as prosecution witnesses.

The youth of the prisoners, especially MacDonald who was just 15, created a strong sensation in the court. All three were sentenced to be executed on 22 April 1812 on the High Street in Edinburgh opposite the stamp office, close to where the murder had occurred, with the body of Mackintosh to be delivered to Alexander Monro, the Professor of Anatomy at Edinburgh University, for dissection. ${ }^{62}$ George Napier and John Grotto were brought before the court a couple of days later but pleaded guilty to one robbery each. The Advocate Depute restricted the charge so they would face a punishment short of the death sentence and they were to be transported for 14 years. ${ }^{63}$ However, in a report sent to the Secretary of State, David Boyle, the Lord Justice Clerk, stated that, due to the alarming nature of the crime and the fact that it had occurred on the heavily frequented streets of Edinburgh, he could see no reason for the law not to take its course for the three boys facing the noose. ${ }^{64}$ Following their execution it was reported that there had been 
evident sympathy for them but the article added that their execution was intended as a dreadful and lasting example and that this motivation was "the only justification of so strong a measure." 65 Following this case the category of 'murder and robbery' was added to the return of persons committed to trial in Scotland for the years 1811-1814 presented to Parliament, again demonstrating the widespread attention the circumstances of the crime and its aftermath had attracted. ${ }^{66}$

In his work on the first half of the nineteenth century, Donnachie demonstrated that crimes were committed overwhelmingly by males, the vast majority of whom were under 30 years of age ${ }^{67}$ The current chapter supports this arguement and has found that, instead of serving as the lasting and dreadful example intended, the above case was one of several in the early nineteenth century where not only the fears over the prevalence of the crime but also the youth of the offenders would be dwelled upon. In the following year, the death sentence was handed down to John McDonald, age 20, and James Williamson Black, age 18, for murder and robbery, and the judges delivered their opinions of the case at length. They expressed astonishment that in a country "so long distinguished for knowledge and virtuous conduct" so many instances of youthful depravity should have lately occurred. As in the case discussed above, the judges lamented that they were obliged to "recur to those more striking and awful punishments which our law enjoins." 68 As well as an increase in the number of executions, this period also witnessed cases where three or even four criminals were executed for the same property offence. The fact that there were no similar cases in the second half of the eighteenth century serves to further demonstrate that there was a determination in the early years of the nineteenth century to make more stark examples of those engaged in criminality.

Richard Smith, age 16, was found guilty of housebreaking and theft and, despite the jury's recommendation to mercy on account of his young age, he was executed in May 1820. ${ }^{69}$ Similarly, James Ritchie, age 17, was condemned in Aberdeen for stealing 30 sheep from the parks of Gordon Castle. Despite a recommendation to mercy and zealous endeavours on the part of the local clergy, university professors and the Duke of Gordon to obtain a remission, Lord Sidmouth, the Secretary of State, refused on account of the magnitude of the crime. ${ }^{70}$ There are numerous other examples of the jury recommending an offender to mercy where the judges or the Lord Justice Clerk, in correspondence with the Home Office, declined to support the recommendation, believing that severe examples needed to be made. In 1817 John Larg and James Mitchell 
were charged with having broken into the house of William McRitchie and as having stolen two papers that they believed to be bank notes, although it was later discovered that they were worthless papers of no value. When their defence attempted to object to the charge the prosecutor answered that in cases such as theirs the value of the item stolen was irrelevant. Despite finding them guilty of the crime, the jury had recommended mercy as no personal violence had been used against the occupants of the house. However, the judges were not prepared to support the recommendation as they reiterated that the offenders had been in possession of a pistol which constituted a threat of personal violence against the home owner. They added that any hopes of a pardon were "precarious indeed." 71 The two men were subsequently executed.

The important balance between the need to make strong punitive statements at times of increased capital convictions and the exercising of judicial discretion was also evident in the following case tried by the High Court in Edinburgh in February 1823. Charles McLaren and James McEwan, both age 14, and Thomas Grierson, age 13, were capitally convicted for housebreaking and theft. ${ }^{72}$ They had unanimously been recommended mercy by the jury due to their youth and a few days before their scheduled execution date on 12 February the Lord Justice Clerk reported to the High Court that the full details of the case had been sent directly to the Home Secretary, Robert Peel. He added that he had no doubt that remissions of the death sentences would arrive for the young offenders but, owing to the state of the roads due to the weather, six London mails were running late. Therefore, it was believed to be absolutely necessary for the court to use its authority to stay the execution until 26 February to allow time for the remissions to arrive. ${ }^{73}$ They finally did so, and the boys were sentenced to be transported for life. ${ }^{74}$ This confidence that they would be pardoned goes some way towards explaining why they were capitally convicted in the first place, when a restriction of the punishment earlier in the proceedings could have been exercised as in other cases of a similar nature. In sentencing these young boys to death, the court wanted to make a poignant statement, but they also clearly intended their subsequent remission. The handling of their case from conviction to pardoning was a prime example of the pulling of Hay's levers of fear and mercy in the punishment of property offences in this period. ${ }^{75}$

When breaking down the total number of executions across the period into category of offence, it becomes clear that the sheer number of property offenders who suffered at the scaffold was subject to a 
greater degree of chronological fluctuation than the figures for murder. The 1820s saw an increase in the number of executed murderers which continued into the 1830s. In addition, in his study of Scottish homicide rates, King demonstrated that between 1805 and 1814 there was an average of 1.0 recorded murder per 100,000 head of Scotland's population. By the 1830s this had risen to 1.75 and by the 1840 s the figure was 2.6. ${ }^{76}$ However, the marked upturn in the number of executions in early nineteenth-century Scotland was primarily due to an increase in the number of executions for property offences which doubled between 1810 and 1819 compared to the previous decade and remained at a similar level in the 1820s. Donnachie stated that, within the overall number of criminal investigations, property offences rose from making up slightly more than half the total number in 1810 to $75 \%$ by $1830 .{ }^{77}$ The parliamentary returns for Scotland available for this period also demonstrate how the overwhelming majority of those committed for trials had carried out property offences. ${ }^{78}$ Furthermore, this study has found that property offences made up $60 \%$ of the total number of executions between 1800 and 1809 , rising to $80 \%$ between 1810 and 1819 . It is important to note here that while the rise in the number of executions for property offences may be, in part, attributable to an increase in crimes committed, it is likely that a more efficient standard of policing and apprehension was also significant. ${ }^{79}$ In addition, this study argues that judicial opinion and public discourse were crucial in dictating Scotland's increased use of capital punishment in the early nineteenth century and that nowhere was this more evident than in the use of capital punishment for the crime of robbery.

The crime of robbery accounted for $34 \%$ of the total property offenders sent to the gallows in Scotland across this period. In terms of property crimes, only capital convictions for housebreaking and theft sent more malefactors to their death. Chapter 2 demonstrated that, although robbery had been used as an indicator of the prevalence of crime in England since at least the mid-eighteenth century, in Scotland the offence did not appear to cause the same level of concern within the central criminal courts until the early nineteenth century. In addition, it was not until the second and third decades of the nineteenth century that the offence began to permeate crime reporting in the Scottish newspapers. The pattern for the capital conviction and execution of Scottish robbers can be linked to wider trends in the country's use of the death sentence to some extent. For example, the number of executions for robbery almost doubled between 
the late 1770s and 1780s and there were discernible links to the wider difficulties facing the authorities in finding a suitably harsh alternative in lieu of the penal option of transportation. In addition, 60 of a total $114(53 \%)$ of all executions for robbery occurred between 1810 and 1829, and correlated with the increase in the number of executions overall. Of these, 50 of the 60 executions occurred following trials before either the High Court in Edinburgh or the Western Circuit sitting at Glasgow. Again, this reinforces the centre-periphery dichotomy in the punishment of property offences highlighted by King and Ward. ${ }^{80}$ Although nineteenth-century Scottish crime has not received the same level of historical attention as experiences south of the border, Kilday highlighted that fears over a robbery epidemic were similarly evident in Scotland as in England despite the much lower number of prosecuted cases north of the border. ${ }^{81}$ In turn, the editorial rhetoric employed when reporting upon robbery cases that resulted in an execution in various ways epitomised judicial and press responses to the perceived rise in serious crime in Scotland in the early nineteenth century and goes some way towards explaining the high proportion of capitally convicted robbers who were subsequently executed.

When the Lord Justice Clerk sentenced William McGhee and Charles Britton to death for the crimes of robbery and stouthrief in 1820 he noted the frequency of this type of crime. They had broken into the house of James Drennan, threatened him and had stolen several items. $\mathrm{He}$ added that, while the offence had been a long-standing problem in a sister kingdom, it had been a rare occurrence in Scotland until recently. ${ }^{82}$ Although stouthrief was not new to the Scottish records, charges relating to this crime were somewhat sporadic until the early nineteenth century. In addition, there were several cases of robbery tried in the eighteenth century where stouthrief was not additionally charged. Therefore, this study argues that, in charging the offence synonymously with robbery, the courts were seeking to mark out certain cases, and perhaps secure capital convictions and justify the subsequent executions in the face of rising numbers of capital convictions for property offences more generally.

Similar lamentations over Scotland's increased recourse to the death sentence, and comparisons with practices in England, were evident in several other cases in this period. As noted above, most executions for robbery followed trials in Scotland's central belt cities of Edinburgh and Glasgow. Although Edinburgh had consistently accounted for a sizeable proportion of the total number of executions across the century under examination, in the early nineteenth century the Western Circuit sitting 
at Glasgow was sending as many, and in some years more, offenders to the gallows. This fact was noted, and lamented, by contemporaries. In 1824 John McCrevie was capitally convicted by the Glasgow court for two different acts of robbery and stouthrief that had involved forcible entry into houses, and in one case the beating of the owner with a poker, and the theft of various items. Two of his accomplices had fled and were outlawed for failing to appear in court. The judge, Lord Meadowbank, stated that he had no hope of a pardon as the perpetration of these crimes of late in the area threatened the security of the inhabitants and thus required a severe response. ${ }^{83}$ Similarly strong sentiments had been expressed during the trial of Thomas Kelly and Henry O'Neil for three acts of highway robbery in 1814. The Lord Justice Clerk stated that the High Court was determined, by the most prompt and vigorous administration of justice, to punish offences of that kind to correct the "loose manners of the time." 84 The Caledonian Mercury added that it was due to the frequency of this offence "formerly little known in Scotland" that the court was induced to execute the men at the scene of the last robbery. ${ }^{85}$

Chapter 5 will demonstrate that the period between the mid-eighteenth and early nineteenth century was one of transition in terms of the staging of the public execution spectacle, including the locations at which it was carried out. The chapter will show that executions across this period were predominantly carried out at an established common place in each circuit city. However, between 1740 and 1834, there were 53 malefactors sentenced to be executed at, or very near, the scene of their crime with 32 of these cases having occurred between 1801 and 1834. This chapter has already noted the concentrated use of crime scene executions in northern Scotland during the decade following the defeat of the 1745 Jacobite Rebellion. In addition, an in-depth examination of the drivers behind Scotland's use of crime scene executions between 1801 and 1841 has been provided elsewhere and has demonstrated that their increased and concentrated usage in the early nineteenth century provides a reverse pattern to practices in England. ${ }^{86}$ However, it is beneficial to contextualise the deviation from the established common places of execution within this chapter's investigation of the increased use of capital punishment more widely in the first third of the nineteenth century. There were discernible similarities in some cases to justify hanging an offender at the scene of their crime, such as the youth of the offenders or the perceived prevalence of the crime they had committed. In addition, within the increased space dedicated to crime reporting in the newspapers, there 
were calls for some further severity to quell the unprecedented numbers facing the hangman's noose. A reading of judicial opinion when ordering that an offender be executed at the scene of their crime reveals similar attitudes to those previously discussed in this chapter, namely a lamentable dismay at the necessity to resort to more striking and severe punishments. These executions were yet another distinct Scottish response to the rising numbers of capitally convicted offenders in Britain and serve to further demonstrate that, although there were similar attitudes and practices discernible north and south of the border, Scotland's capital punishment history in this period cannot be readily assimilated into the more Anglo-centric British narrative.

\section{Conclusion}

To conclude, despite the rich historiography that has explored the storied history of capital punishment in eighteenth and early nineteenthcentury Western Europe, studies of the Scottish experience have been relatively limited. However, a key argument running throughout the current study is that this period was one of discussion and debate over the use of the death sentence and the merits of public punishment in Scotland. Chapter 2 explored the relative autonomy of the Scottish legal system in the wake of the 1707 Union which meant that many of the capital statutes that made up the 'Bloody Code' were not extended north of the border. In addition, it detailed some of the nuances of the Scottish court system that impacted upon their use of the death sentence. To advance our understanding of Scotland's use of capital punishment, the current chapter provided an examination of three key periods in the country's execution history. It has demonstrated that an exploration of the drivers behind the use of the death sentence at each of these junctures can reinforce some of the arguments within the broader capital punishment narrative primarily focused upon England. However, the motivations for the meting out of the death sentence for specific crimes at certain times were rooted in a unique Scottish context.

The mid-eighteenth century was a period of debate and concern over criminality and various parts of Britain witnessed an increase in capital convictions. However, while studies of England have shown that concerns over criminality were very much a problem facing the authorities of London and its surrounding areas, the current chapter has demonstrated that in Scotland the use of capital punishment was explicitly linked to the aftermath of the 1745 Jacobite Rebellion. The death sentence was 
employed as part of wider attempts to permanently stabilise the peripheral north, an area which, in parts, had been largely impenetrable to the central government authorities. Certain crimes, such as cattle theft, had been a long-standing problem in the Highlands due to a combination of the lack of strong central legal authority and embedded local customs, and offences of this kind were especially targeted for severe punishment. In the ten-year period between 1746 and 1755 executions following trials before the Northern Circuit accounted for over half the total number in Scotland. In addition, this period saw the highest proportion of capitally convicted offenders subsequently executed and the highest number of executions per 100,000 head of Scotland's population. This further demonstrates the determination of the authorities to be seen to be enacting vigorous, and centrally driven, justice at a more local level. In this sense, this chapter's examination of mid-eighteenth-century northern Scotland provides some reinforcement to Garland's argument for the Early Modern period, namely that the death penalty was afforded a central role in the task of state security. ${ }^{87}$ In addition, although this study broadly reinforces King and Ward's argument that capital punishment for property offences was more frequently deployed in central areas than in the peripheries, particularly in the early nineteenth century, it has shown that the mid-eighteenth century provides something of a caveat. ${ }^{88}$

Following the mid-eighteenth century, capital convictions decreased and remained relatively stable in Scotland until the 1780s when they doubled compared to the previous decade. The drivers behind this marked increase can be more readily situated within the wider British context than the earlier peak as both the English and Scottish authorities faced difficulties due to the temporary cessation of the penal option of transportation. In addition, while levels of capital punishment had been impacted by demobilisation since at least the mid-eighteenth century in England, it was not until the 1780s that members of the armed forces notably littered the Scottish court records. Despite these similarities, this chapter has again identified a unique Scottish response to this British problem. In England, historians have shown that there was not only an increase in the proportion of capitally convicted offenders executed, there was also a determination not to extend the Royal mercy for certain property offences. ${ }^{89}$ Comparatively, building upon Chap. 2, the current chapter has demonstrated that the nuances of the Scottish court system, particularly the practice of allowing the courts to restrict the level of punishment to be meted out before the commencement of potentially capital 
trials, required the availability of a suitably harsh secondary punishment in transportation. When it was temporarily unavailable, the courts were unable to exercise this discretion as frequently and thus passed the death sentence in cases of property crime where previously they would likely have restricted the punishment, something they would do so again when transportation to Australia was established. However, while the sheer number of death sentences and executions increased, particularly for property offences, there was not the same determination to send all capitally convicted offenders to the scaffold. In fact, the proportion of capitally convicted property offenders who were executed fell slightly in the 1780s compared to the previous decade.

As in the previous periods, Scotland was not alone in witnessing an increase in capital punishment in the early nineteenth century. However, again, this chapter has identified unique Scottish responses to the problem. For example, historians have shown that the increasing gap between the numbers of capital convictions and executions in England in the second and third decades of the nineteenth century meant that the capital code became unworkable. ${ }^{90}$ Comparatively, this chapter has demonstrated more proportional continuity in the number of capitally convicted offenders who were executed between the 1770s and 1820s in Scotland. A potential explanation for this may be found in the fact that there were far lower numbers of malefactors who faced the death sentence north of the border throughout the period under examination in this study. In addition, a reading of judicial opinion when sentencing offenders demonstrates that previous acknowledgements of Scotland's lesser recourse to the death sentence in the newspapers turned to lamentations over its increased use in the early nineteenth century. In turn, the perceived need for some further severity to quell the rising number of people facing the hangman's noose was used in the courts and in the press to justify the use of crime scene executions, a penal option not used to a similar extent in Scotland since the mid-eighteenth century.

To conclude this chapter, it is important to note that by 1834 , the end of the period under examination in this study, the use of capital punishment in Britain had undergone major changes judicially, ideologically and practically. The number of offenders executed in Scotland, which had doubled between the first and second decades of the nineteenth century and had risen further in the 1820s, halved in the 1830s. Furthermore, similar to the situation in England, by the 1830s murder was the predominant crime sending offenders to the scaffold as property 
offenders increasingly received the non-capital punishments of transportation and prison sentences, a fact also noted by Riggs in his investigation of prosecution decisions and the restriction of the charges in cases of property crime. ${ }^{91}$ Compared to the figure for murder, which had remained steady in the three decades between the 1810s and the 1830s, the proportion of capitally convicted property offenders decreased in the 1820s compared to the decade between 1810 and 1819. Thus, the late 1820s and 1830s in Scotland would provide some reinforcement to Gatrell's argument that the authorities could not feasibly execute large proportions of property offenders. ${ }^{92}$ By 1841 Lord Cockburn, a Justiciary Court judge, noted an aversion to capital punishment on the part of the courts, even for crimes such as rape and robbery, the latter of which had been a particular concern in Scotland two decades earlier. ${ }^{93}$ Furthermore, while there were still discussions over the believed prevalence of certain crimes within the newspapers, their attention increasingly turned towards debates over the reform of the capital code. For example, Chap. 2 demonstrated that the crime of forgery ceased to result in offenders being sent to the gallows, a fact noted by contemporary reformers, and that the English legislation passed relating to the offence was extended to Scotland.

\section{Notes}

1. See John Louthian, The Form of Process before the Court of Justiciary in Scotland (Edinburgh: 1732); David Hume, Commentaries on the Law of Scotland Respecting Crimes, Volumes 1 and 2 (Edinburgh: 1819); Sir Archibald Alison, Principles of the Criminal Law of Scotland (Edinburgh: William Blackwood, 1832).

2. J. M. Beattie, Crime and the Courts in England 1660-1800 (Oxford: Oxford University Press, 1986), 532-533.

3. For an analysis of the increase in committals for theft in Staffordshire, see Douglas Hay, "War, Dearth and Theft in the Eighteenth Century: The Record of the English Courts", Past and Present 95 (1982): 117-160. For an analysis of Essex see Peter King, Crime, Justice and Discretion in England 1740-1820 (Oxford: Oxford University Press, 2000), 153-168.

4. Richard Ward, "Print Culture, Moral Panic, and the Administration of the Law: The London Crime Wave of 1744", Crime, History and Societies 16 (2012): 5-24, 10.

5. Caledonian Mercury, Thursday, 8 November 1744, 4; NAS JC7/24/497.

6. For a more detailed analysis, see Nicholas Rogers, "Confronting the Crime Wave: The Debate over Social Reform and Regulation, 
1749-1753", in Stilling the Grumbling Hive: The Response to Social and Economic Problems in England, 1689-1750, ed. by Lee Davison, Tim Hitchcock, Tim Keirn and Robert B. Shoemaker, 77-98, Stroud: Alan Sutton, 1992.

7. Beattie, Crime and the Courts, 521 .

8. Geoffrey Plank, Rebellion and Savagery: The Jacobite Rising of 1745 and the British Empire (Philadelphia: University of Pennsylvania Press, 2006), 22-25.

9. T. M. Devine, The Scottish Nation 1700-2000 (London: Penguin Press, 1999), 41.

10. Bruce Lenman, The Jacobite Risings in Britain 1689-1746 (Aberdeen: Scottish Cultural Press, first published 1980, this edition 1995), 222.

11. The Rise of the Present Unnatural Rebellion Discover'd; and the Extraordinary Power and Oppression of the Highland Chiefs Fully Display'd (London: 1745), 13.

12. Stephen J. Davies "Law and Order in Stirlingshire, 1637-1747" (PhD Thesis, University of St Andrews, 1984). For his discussion of the demise of the old legal order between 1690 and 1747, see 443-493.

13. NAS JC11/13/19-28; Derby Mercury, Friday, 16 September 1748, 4.

14. NAS JC11/13/15.

15. Devine, Scottish Nation, 46.

16. TNA SP54/37/1. Letter dated 3 October 1747.

17. Colin Kidd, Subverting Scotland's Past: Scottish Whig Historians and the Creation of an Anglo-British Identity 1689-c.1830 (Cambridge: Cambridge University Press, 1993), 155.

18. David G. Barrie and Susan Broomhall, "Public Men, Private Interests: The Origins, Structure and Practice of Police Courts in Scotland, c.1800-1833", Continuity and Change 27 (2012): 83-123, 88.

19. NAS JC11/14/321.

20. Peter King and Richard Ward, "Rethinking the Bloody code in Eighteenth-Century Britain: Capital Punishment at the Centre and on the Periphery", Past and Present 228 (2015): 159-205, 160.

21. Sharon Howard, "Investigating Responses to Theft in Early Modern Wales: Communities, Thieves and Courts", Continuity and Change XIX (2004): 409-430, 411-414.

22. Scots Magazine, Monday, 7 July 1755, 39.

23. NAS JCl1/16/247.

24. Derby Mercury, Friday, 17 July 1752, 1.

25. NAS JC11/17/239.

26. This is evidenced by the fact that, of the total 35 executions in the $1770 \mathrm{~s}$, 25 had occurred between 1770 and 1774, before the outbreak of the war. Therefore, there was not an immediate increase in capital convictions or executions in Scotland. 
27. Beattie, Crime and the Courts, 584 .

28. Simon Devereaux, "Imposing the Royal Pardon: Execution, Transportation and Convict Resistance in London, 1789", Law and History Review 25 (2007): 101-138, 120.

29. Hay, "War, Dearth and Theft in the Eighteenth Century", 145.

30. Beattie, Crime and the Courts, 532-533.

31. For a more extensive study of Scottish soldiers in the British army, see Steve Murdoch and A. Mackillop (eds.), Fighting for Identity; Scottish Military Experience c.1550-1900 (Leiden: Brill, 2002).

32. NAS JC13/24/67.

33. Ian Donnachie, "Scottish Criminals and Transportation to Australia, 1786-1852", Scottish Economic and Social History 4 (1984): 21-38, 22.

34. Gentleman's Magazine and Historical Chronicle, Vol. 56 (London: 1786), 264.

35. NAS JCl1/38/27.

36. TNA HOl02/51/267; HOl02/51/365.

37. NAS JC7/41/411.

38. NAS JC7/42/67. Note that in Scotland there were 15 jury members and a majority decision was sufficient to return a verdict. Within the court records it would be stated whether the jury had unanimously found the accused guilty or not guilty, or if they had reached their decision by a "plurality of voices", but, in most of these cases, the ratio would not be stated.

39. Caledonian Mercury, Wednesday, 4 February 1784, 3.

40. NAS JCl1/38/63.

41. TNA HOl02/51/497.

42. TNA HOl02/50/11.

43. King, Crime, Justice and Discretion, 291.

44. TNA HOl02/52/15.

45. TNA HOl02/50/126; HOl02/50/131.

46. For select studies of the English experience, see V. A. C. Gatrell, The Hanging Tree: Execution and the English People 1770-1868 (Oxford: Oxford University Press, 1994); Clive Emsley, Crime and Society in England 1750-1900 (London: Routledge, 2013); King, Crime, Justice and Discretion.

47. See Ian Donnachie, "The Darker Side: A Speculative Survey of Scottish Crime During the First Half of the Nineteenth Century", Journal of the Economic and Social History of Scotland 15 (1995): 5-24; Peter King, "Urbanisation, Rising Homicide Rates and the Geography of Lethal Violence in Scotland 1800-1860", History 96 (2011): 231-259. For a study of the subsequent reduction of capital punishment in favour of sentencing the punishments of imprisonment or transportation, 
see Paul T. Riggs, "Prosecutors, Juries, Judges and Punishment in Early Nineteenth-Century Scotland", Journal of Scottish Historical Studies 32 (2012): 166-189.

48. Emsley, Crime and Society in England, 265-267.

49. Gatrell, Hanging Tree, 544.

50. Gatrell, Hanging Tree, 103.

51. The figures for the 1820 s differ as there were three executions for treason and 21 remissions. If we remove these figures from the totals the percentage of executions rises to $52 \%$. In addition, the period $1830-1834$ saw $70 \%$ of those convicted executed. This was arguably because, by this time, more capital convictions were for murder and thus were less likely to be pardoned.

52. M. Anne Crowther, "Crime, Prosecution and Mercy: English and Scottish Practice in the Early Nineteenth Century", in Kingdom's United? Great Britain and Ireland since 1500, ed. by S. J. Connolly, 225-238, 233, Dublin: Four Courts Press, 1999.

53. David Turnock, The Historical Geography of Scotland since 1707 (Cambridge: Cambridge University Press, 1982), 166.

54. Andrew Gibb, "Industrialisation and Demographic Change: A Case Study of Glasgow 1801-1914", in Population and Society in Western European Port Cities c. 1650-1939, ed. by Richard Lawton and Robert Lee, 37-73, 46, Liverpool: Liverpool University Press, 2002.

55. Bruce Lenman, Integration and Enlightenment Scotland 1746-1832 (Edinburgh: Edinburgh University Press, 1981), 152.

56. Barrie and Broomhall, "Public Men, Private Interests", 91, 104.

57. King and Ward, "Rethinking the Bloody Code".

58. Anne-Marie Kilday, “Contemplating the Evil Within: Examining Attitudes to Criminality in Scotland 1700-1840", in Crime, Courtrooms and the Public Sphere in Britain 1700-1850, ed. by David Lemmings, 147-166, 159, Surrey: Ashgate, 2012.

59. Scots Magazine, Sunday, 1 January 1815, 31.

60. Scots Magazine, Saturday, 1 November 1817, 88.

61. Enumeration of the Inhabitants of Scotland, taken from the Government Abstracts of 1801, 1811, 1821 (Glasgow: 1823), 52.

62. NAS JC8 $/ 8 / 266$.

63. NAS JC8/9/1.

64. TNA HOl02/55/66.

65. Aberdeen Journal, Wednesday, 29 April 1812, 3.

66. Parliamentary Papers, Vol. XI (163) 1814-1815. A Return of Persons, Male and Female, Committed in the Years 1811, 1812, 1813 and 1814 to the Several Gaols in Scotland.

67. Donnachie, "The Darker Side", 20. 
68. NAS JC8/9/232; Scots Magazine, Monday, 7 June 1813, 36.

69. NAS JC13/48/33.

70. Scots Magazine, Monday, 1 June 1818, 85.

71. NAS JC8/11/269; Caledonian Mercury, Thursday, 23 January 1817, 4.

72. NAS JC8/17/7.

73. NAS JC8/17/21.

74. TNA HOl04/6/180.

75. Douglas Hay, "Property, Authority and the Criminal Law", in Albion's Fatal Tree: Crime and Society in Eighteenth-Century England, ed. by Douglas Hay, Peter Linebaugh, John G. Rule, E. P. Thomson and Cal Winslow, 17-63, 51, London: Allen Lane, 1975.

76. King, "Urbanisation, Rising Homicide Rates and the Geography of Lethal Violence", 237.

77. Donnachie, "The Darker Side", 9-10.

78. Parliamentary Papers, Vol. XI (163) 1814-1815; Parliamentary Papers, Vol. XXXV (499) 1831-1832. Return of Number of Persons Brought for Trial for Capital Crimes before Justiciary Courts in Scotland, 1827-1831.

79. This is a fact noted by Donnachie in "The Darker Side", 6.

80. King and Ward, "Rethinking the Bloody Code".

81. Anne-Marie Kilday, "Hell-Raising and Hair-Razing: Violent Robbery in Nineteenth-Century Scotland", The Scottish Historical Review XCII (2013): 255-274.

82. Morning Post, Wednesday, 16 February 1820, 4.

83. Caledonian Mercury, Saturday, 17 April 1824, 4.

84. Scots Magazine, Sunday, I January 1815, 31.

85. Caledonian Mercury, Thursday, 26 January 1815, 3; NAS JC8/11/10.

86. Rachel Bennett, "An Awful and Impressive Spectacle: Crime Scene Executions in Scotland, 1801-1841", Crime, History and Societies 21 (2017): 101-123. For studies of crime scene executions in England, see Steve Poole, “A Lasting and Salutary Warning: Incendiarism, Rural Order and England's Last Scene of Crime Execution", Rural History 19 (2008): 163-177; Steve Poole, "For the Benefit of Example: Crime Scene Executions in England, 1720-1830", in A Global History of Execution and the Criminal Corpse, ed. by Richard Ward, 71-101, Basingstoke: Palgrave MacMillan, 2015.

87. David Garland, "Modes of Capital Punishment: The Death Penalty in Historical Perspective", in America's Death Penalty: Between Past and Present, ed. by David Garland, Randall McGowen and Michael Meranze, 30-71, 30, London: New York University Press, 2011.

88. King and Ward, "Rethinking the Bloody Code".

89. See Beattie, Crime and the Courts, 584; Devereaux, "Imposing the Royal Pardon", 120. 
90. See Emsley, Crime and Society in England, 265-267; Gatrell, Hanging Tree, 544 .

91. Riggs, "Prosecutors, Juries, Judges and Punishment", 166-189.

92. Gatrell, Hanging Tree, 544.

93. Henry Cockburn, Circuit Journeys (Edinburgh: David Douglas, 1889), 92.

Open Access This chapter is licensed under the terms of the Creative Commons Attribution 4.0 International License (http://creativecommons.org/licenses/ by $/ 4.0 /)$, which permits use, sharing, adaptation, distribution and reproduction in any medium or format, as long as you give appropriate credit to the original author(s) and the source, provide a link to the Creative Commons license and indicate if changes were made.

The images or other third party material in this chapter are included in the chapter's Creative Commons license, unless indicated otherwise in a credit line to the material. If material is not included in the chapter's Creative Commons license and your intended use is not permitted by statutory regulation or exceeds the permitted use, you will need to obtain permission directly from the copyright holder.

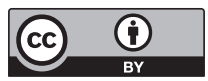

